\title{
TEKNIK BULEKUNG SEBAGAI STRATEGI MEMPERKUAT KETAHANAN PANGAN SKALA RUMAH TANGGA DISAAT PANDEMI COVID-19
}

\author{
Icha Al'May Syafa ${ }^{1}$, Azimatus Zahro ${ }^{2}$, M. Trihudiyatmanto ${ }^{3 *}$ \\ $12^{*}$ Universitas Sains Al-Qur'an (UNSIQ) \\ *E-mail: trihudiyatmanto@unsiq.ac.id
}

\begin{abstract}
ABSTRAK
Kuliah Pengabdian Masyarakat (KPM) Tematik Covid Universitas Sains Al-Quran merupakan suatu bentuk pendidikan dan pengabdian yang dilakukan untuk memberikan pengalaman belajar kepada mahasiswa agar mahasiswa terlibat langsung dalam membantu masyarakat di tengah pandemic covid-19. Wabah covid-19 menyebar dengan sangat cepat sehingga menyebabkan efek yang sangat luas baik dari segi Kesehatan, social maupun ekonomi. Dengan menurunnya perekonomian efek covid nyatanya telah menjalar ke sector lain, termasuk sector pangan.

Budidaya lele dan kangkung dalam ember bias menjadi alternatif yang digunakan untuk menjaga ketersediaan atas kebutuhan konsumsi protein keluarga kelas menengah dengan memanfaatkan lahan sempit di sekitar rumah/ hunian.

Pengabdian kepada masyarakat ini dilakukan di Desa Sojokerto, Kecamatan Leksono, Kabupaten Wonosobo, Provinsi Jawa Tengah pada tanggal 4 Februari 2021 - 17 Maret 2021 bersama Kelompok Wanita Tani (KWT), ibu-ibu PKK dan warga desa Sojokerto. Metode yang digunakan dalam pengabdian adalah dengan penyuluhan atau sosialisasi yang meliputi pembukaan, pelatihan, pendampingan dan penyerahan produk. Berhasilnya kegiatan ini ditandai dengan antusiasme seluruh peserta yaitu masyarakat yang terlibat dalam proses budidaya ikan lele dalam ember pada saat program kerja bulekung dilaksanakan.
\end{abstract}

Kata kunci: Bulekung, Ketahanan Pangan.

\section{BULEKUNG TECHNIQUES AS A STRATEGY TO STRENGTHEN FOOD SECURITY HOUSEHOLD SCALE IN PANDEMY COVID-19}

\begin{abstract}
The Covid Thematic Community Service Lecture (CSL) at the University of Sains Al-Quran is a form of education and service that is carried out to provide learning experiences to students so that students are directly involved in helping the community in the midst of the Covid-19 pandemic. The Covid-19 epidemic spreads very quickly, causing a very broad effect both from a health, social and economic point of view. With the decline in the economy, the effect of Covid has spread to other sectors, including the food sector.

The cultivation of catfish and kale in buckets can be an alternative to maintain the availability of protein consumption needs of middle-class families by utilizing the narrow land around the house / residence.

This community service was carried out in Sojokerto Village, Leksono District, Wonosobo Regency, Central Java Province on February 4, 2021 - March 17, 2021 with the Women's Farmers Group (WFG), PKK women and Sojokerto village residents. The method used in the community service is counseling or socialization which includes opening, training, mentoring and product delivery. The success of this activity was marked by the enthusiasm of all participants, namely the community involved in the process of cultivating catfish in buckets at the time the Bulekung work program was implemented.
\end{abstract}

Keywords: Bulekung, Food Security

\section{PENDAHULUAN}

Salah satu program kerja KPM Tematik kelompok 40 Universitas Sains Al-Qur'an saat pandemic Covid-19 ini adalah program pembuatan Bulekung (budidaya lele dan kangkung dalam ember) di Desa Sojokerto, Kec Leksono untuk memenuhi kebutuhan pangan dalam keluarga disaat pandemi 
Covid-19. Budikdamber atau bulekung merupakan salah satu model hidroganik yang sederhana. Sistem ini menggunakan ember untuk budidaya ikan dan di atasnya ditanami sayuran dengan memanfaatkan kotoran ikan sebagai pupuk atau nutrisi tanaman. Sistem ini bermanfaat untuk menyediakan kebutuhanakan protein hewani dan sayuran, serta memudahkan masyarakat mendapatkan ikan dan sayur. Budidaya lele dalam ember menjadi teknik yang popular karena beberapa alas an diantaranya yaitu adanya aktivitas work from home akibat covid-19 yang menumbuhkan trend "bertani di rumah". Kedua, bulekung tidak membutuhkan keterampilan khusus. Perawatan yang mudah sehingga aktivitas bulekung bias dilakukan oleh banyak orang dan praktis. Ketiga, lele adalah komoditas perikanan yang sudah sangat populer. Keempat, biaya yang diperlukan untuk pembuatan budikdamber relative terjangkau bahkan beberapa komponen dapat digantikan dengan barang-barang bekas. Selain itu, wadah budidaya ikan yang digunakan mudah didapatkan, hemat dalam penggunaan air serta tambahan penanaman sayuran kangkung diatas ember.

Dengan adanya Bulekung di Desa Sojokerto bertujuan untuk meningkatkan pemahaman serta member kesempatan kepada masyarakat untuk melakukan praktik bulekung sebagai bentuk kemandirian pangan produksi skala rumah tangga dan menunjang kondisi ekonomi masyarakat itu sendiri dengan memanfaatkan pekarangan rumah.

\section{LANDASAN TEORI}

\section{Budikdamber ( budidaya ikandidalam ember)}

Teknik Budikdamber dikembangkan oleh Bapak Juli Nursandi, S.Pi.,M.Si dari Politeknik Negri Lampung. Teknik ini merupakan teknik pengembangan dari Aquaponik dimana ikan dan tanaman tumbuh dalam satu tempat. Solusi ini didapat untuk mengatasi masalah lahan dalam budidaya tanaman dan ikan. Melalui teknik ini dapat dilakukan oleh masyarakat yang tinggal di pedesaan maupun di perkotaan. Budikdamber sangat bisa diterapkan untuk mengatasi solusi ketahanan pangan keluarga di masa depan. Budidaya ikan dalam ember dengan system aquaponik berpeluang meningkatkan kebutuhan akan protein hewani dan sayuran serta memudahkan masyarakat mendapakan ikan dan sayur di lingkungan tempat tinggal. Selain mudah dilakukan, budikdamber menggunakan media yang kecil, portable hemat air dan tidak membutuhkan listrik. Dalam usaha budidaya ikan, kualitas air merupakan salah satu faktor penting yang berpengaruh terhadap kelangsungan hidup ikan yang di budidayakan. Ikan lele termasuk ikan yang tahan terhadap kualitas air yang minim atau kualitas air yang kurang baik bahkan ikan lele dapat hidup pada kondisi oksigen yang sangat rendah, hal ini disebabkan karena ikan lele mempunyai alat bantu pernafasan berupa arborescant yang dapat mengambil oksigen langsung dari udara. Prosesnya dimana tanaman memanfaatkan unsur hara yang berasal dari kotoran ikan yang apabila dibiarkan di dalam kolam akan menjadi racun bagi ikannya. Lalu tanaman akan berfungsi sebagai filter vegetasi yang akan mengurai zat racun tersebut menjadi zat yang tidak berbahaya bagi ikan, dan suplai oksigen pada air yang digunakan untuk memelihara ikan. Dengan siklus ini akan terjadi siklus saling menguntungkan dan bagi masyarakat yang mengaplikasikannya tentu saja akan sangat menguntungkan, karena lahan yang dipakai tidak terlalu luas. Sehingga dapat diambil manfaat dari keduanya.

\section{Ketahanan Pangan di Era New Normal}

Ketahanan pangan adalah ketersediaan pangan dan kemampuan seseorang untuk mengaksesnya. Sebuah rumah tangga dikatakan memiliki ketahanan pangan jika penghuninya tidak berada dalam kondisi kelaparan atau dihantui rasa kelaparan. World Health Organization 
mendefinisikan tiga komponen utama ketahanan pangan, yaitu ketersediaan pangan, akses pangan dan pemanfaatan pangan. Ketersediaan pangan adalah kemampuan memiliki sejumlah pangan yang cukup untuk kebutuhan dasar. Akses pangan adalah kemampuan memiliki sumber daya secara ekonomi maupun fisik, untuk

mendapatkan bahan pangan ternutrisi. Pemanfaatan pangan adalah kemampuan dalam memanfaatkan bahan pangan dengan benar dan tepat secara proporsional.Ketahanan pangan pada tingkat rumah tangga merupakan landasan bagi ketahanan pangan masyarakat, yang selanjutnya menjadi pilar bagi ketahanan pangan daerah dan nasional. Ketahanan pangan terwujud apabila secara umum telah terpenuhi dua aspek sekaligus. Pertama adalah tersedianya pangan yang cukup dan merata untuk seluruh penduduk. Kedua, setiap penduduk mempunyai akses fisik dan ekonomi terhadap pangan untuk memenuhi kecukupan gizi guna menjalani kehidupan yang sehat dan produktif dari hari ke harisecara mandiri dan mendukung pemerintah dalam mengimplementasikan era New Normal

\section{METODE}

Metode yang digunakan dalam penelitian ini adalah kualitatif dengan pendekatan secara langsung metode ceramah dan praktik.

\section{Waktu dan Tempat}

Penelitian dilaksanakan di Desa Sojokerto, Kec. Leksono, Kab. Wonosobo, Jawa Tengah. Penelitian ini tepatnya dilakukan di dua dusun Desa Sojokerto yaitu Dusun Sojokerto dan Dusun Bangon.

\section{Alat dan Bahan}

Alat dan bahan yang digunakan dalam penelitian ini adalah: Ember berukuran 60 Liter, kawat, Kapas, tang, solder, gelas plastic ukuran $250 \mathrm{ml}$, arang batok kelapa atau arang kayu, air sumur, dan bahan utama benih ikan lele, dan benih tanaman kangkung.

\section{HASIL DAN PEMBAHASAN}

\section{Tahap Persiapan}

Kegiatan pengabdian masyarakat dilaksanakan dengan melakukan observasi untuk mendapatkan informasi mengenai potensi lokal yang perlu dikembangkan. Proses observasi dilakukan dengan melakukan proses wawancara dengan Kepala Desa Sojokerto beserta pengurus KWT (Kelompok Wanita Tani). Setelah memperoleh informasi, kemudian dilakukan penentuan lokasi sesuai rekomendasi dari Desa yaitu dusun Sojokerto dan dusun Bangon.

Kegiatan selanjutnya adalah persiapan alat dan bahan yang diperlukan untuk pembuatan instalasi budidaya ikan dalam ember (budikdamber).

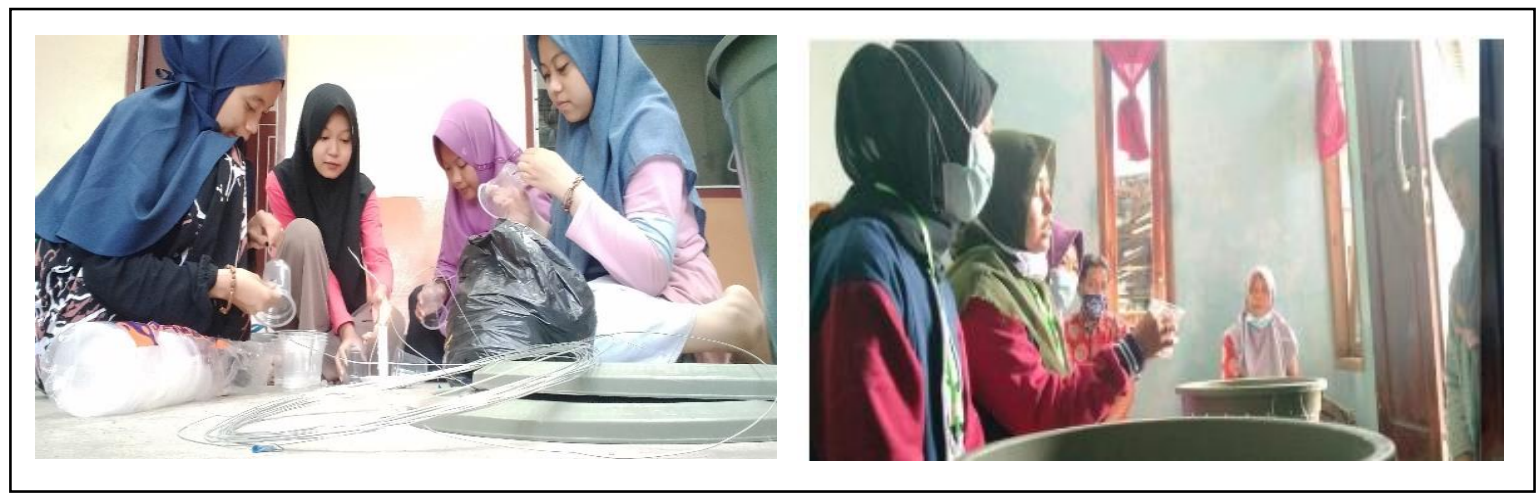


BAKTI BANUA : Jurnal Pengabdian Kepada Masyarakat

Volume 2 No. 22021

e-ISSN : 2722-3736

p-ISSN : 2722-7529

https://ejurnal.stimi-bjm.ac.id/index.php/BBJM/

Gambar 1.1 Persiapan alat dan bahan pembuatan Bulekung dan Penyuluhan kepada Masyarakat

\section{Tahap Pelaksanaan}

Pembuatan bulekung dilakukan sebagai demonstrasi atau percontohan bagi masyarakat agar mengetahui bagaimana bentuk dari pada bulekung. Kegiatan sosialisasi budidaya lele dan kangkung dalam ember (Bulekung) yang pertama dilaksanakan di rumah anggota KWT Dusun Sojokerto, Desa Sojokerto, Kecamatan Leksono, Kabupaten Wonosobo dan yang kedua dilaksanakan di Pertemuan KWT Dusun Bangon, Kecamatan Leksono, Kabupaten Wonosobo. Peserta yang menjadi mitra adalah ibu-ibu KWT dan ibu-ibu PKK yang tinggal di Desa Sojokerto.

Mahasiswa menjelaskan mengenai pengertian budidaya ikan di dalam ember, penjelasan mengenai alat dan bahan yang digunakan untuk membuat instalasi bulekung, cara penanaman tanaman di dalam gelas plastik dan umur penebaran lele yang tepat. Beberapa sayuran yang dapat dibudidayakan dalam bulekung adalah kangkung dan sawi. Sementara untuk ikan yang dapat dibudidayakan adalah lele. Materi lain yang dibahas adalah cara perawatan tanaman dan ikan lele yang tepat termasuk waktu dan cara pergantian air di ember yang baik dan benar.

Demonstrasi pembuatan alat bulekung sangat mudah dilakukan oleh siapa saja karena karakter bulekung sendiri yang memang sangat aplikatif dan mudah diterapkan oleh masyarakat luas. Selanjutnya, masing-masing peserta berkesempatan untuk mencoba pembuatan alat budikdamber agar peserta memahami cara perakitan alat budikdamber yang baik dan benar.

Adapun Cara pembuatan Bulekung adalah sebagai berikut:

1. Siapkan gelas plastik untuk tempat bibit kangkung sebanyak 8-10 buah

2. Lubangi ember menggunakan solder disamping atas

3. Lubangi botol plastik kemasan gelas sebanyak 10-15 di bagian bawah

4. Isikan kapas dan bibit kangkung yang telah direndam air hangat lalu letakkan arang batok kelapa

5. Potong kawat sekitar $10 \mathrm{~cm}$ dan kaitkan untuk pegangan gelas didalam ember.

6. Isi ember dengan air sebanyak 60 liter diamkan selama dua hari.

7. Lalu isikan bibit ikan lele 50 ekordengan ukuran panjang 4-12 $\mathrm{cm}$ kedalam ember.

Terdapat 2 versi dalam peletakan pot media tanam, yaitu dengan memanfaatkan tutup ember yang dilubangi dan menyambungkan gelas plastic sebagai pot media tanam menggunakan kawat. Kelebihanya adalah penggunaan lebih ekonomis jika menggunakan tutup ember namun populasi gelas plastic sebagai pot media tanam hanya berjumlah 8 lubang. Sementara itu untuk versi yang menggunakan lain kapasitas pot media berjumlah 10-12 pot/ ember.

Selama berlangsungnya pelatihan, peserta pelatihan sangat antusias, budidaya kangkung tergolong murah, mudah dan aplikatif. Produk yang dibuat objek pelatihan kepada masyarakat selanjutnya diberikan kepada salah satu warga sebagai percontohan yang bertujuan untuk menarik masyarakat lain yang berada di Desa Sojokerto untuk mencoba budidaya ikan dan sayur dalam satu ember.

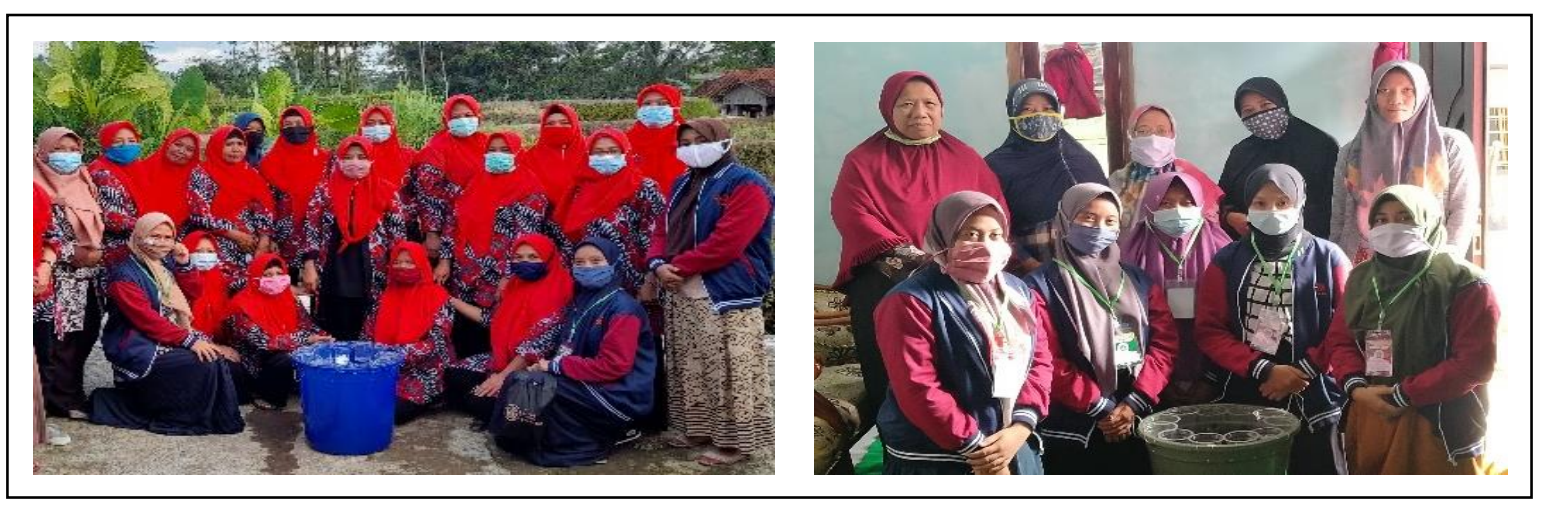




\section{Gambar 1.2 Pelatihan Bulekung Dusun Bangon dan Dusun Sojokerto.}

\section{Tahap Monitoring/ Evaluasi}

Kegiatan pengabdian masyarakat ini dilanjutkan dengan monitoring atau pengawasan terhadap budidaya kangkung dan budidaya ikan dalam ember yang telah diberikan kepada masyarakat.

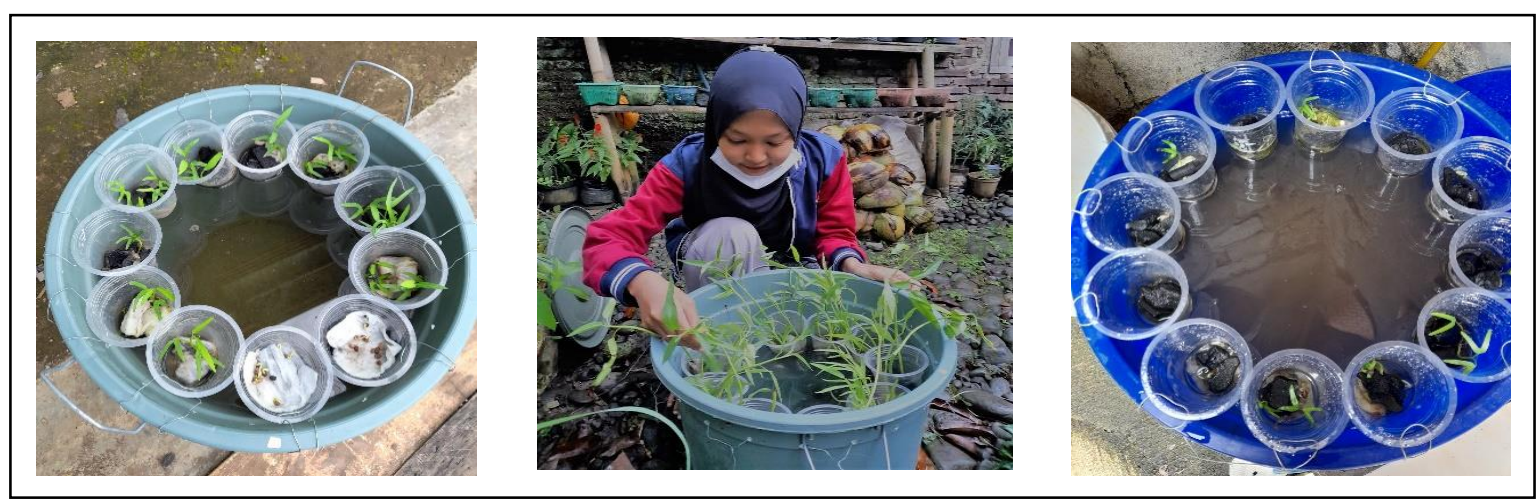

Gambar 1.3 Bulekung Dusun Sojokerto dan Dusun Bangon.

Gambar tengah Hasil Bulekung setelah 12 hari.

Terdapat beberapa kendala yang terjadi seperti matinya beberapa ikan karena pakan yang digunakan terlalu besar, sehingga untuk mencegah pakan mengembang dalam perut ikan pakan harus dihancurkan terlebih dahulu sebelum diberikan.

Kegiatan monitoring tidak dilakukan hingga sayuran dan ikan panen karena keterbatasan waktu. Namun, berdasarkan pengabdian masyarakat yang dilakukan, terdapat adanya keinginan masyarakat untuk melanjutkan program bulekung. Hal ini terbukti dengan keinginan masyarakat untuk merakit sendiri tentang budidaya ikan dalam ember sebagai percontohan. Beberapa masyarakat yang telah mengikuti program pengabdian masyarakat ini juga menyebarkan kepada masyarakat yang belum mengikuti kegiatan.

\section{SIMPULAN}

Dalam menghadapi pandemi Covid-19 tidak hanya tanggungjawab dari pemerintah dalam memulihkan kondisi ekonomi, tetapi perlu adanya peran dari masyarakat untuk mewujudkan strategi pemulihan pasca pandemi. Salah satu cara dalam memberdayakan masyarakat dalam menghadapi pandemi Covid-19 yaitu dengan memperkuat ketahanan pangan rumah tangga dengan teknik budidaya ikan lele dalam ember (budikdamber). Hal ini diperlukan agar rumah tangga dapat mengupayakan pangan untuk dikonsumsi sehari-hari, sehingga mengurangi pengeluaran konsumsi rumah tangga. Pendampingan secara rutin kepada warga penerima manfaat mampu berperan efektif dalam transfer informasi dan keterampilan budikdamber. Dari evaluasi kegiatan, informasi budikdamber lele masih perlu disebarluaskan baik dengan metode penyuluhan langsung kemasyarakat sasaran (secara luring) maupun dengan metode video tutorial (secara daring), sehingga semakin banyak masyarakat yang bias memanfaatkan teknik budidaya ini.

\section{DAFTAR PUSTAKA}

Nursandi. (2018). Budidaya Ikan dalam Ember "Budikdamber" dengan Akuaponik di Lahan Sempit. 
BAKTI BANUA : Jurnal Pengabdian Kepada Masyarakat

Volume 2 No. 22021

e-ISSN : 2722-3736

p-ISSN : 2722-7529

https://ejurnal.stimi-bjm.ac.id/index.php/BBJM/

Tustiyani dan Sinaga. (2018). Sosialisasi Sistem Vertiminaponik di Desa Cidatar, Kecamatan Cisurupan Kabupaten Garut.

Saputri, S. A. D., \& Rachmawatie, D. (2020). Budidaya Ikan Dalam Ember: Strategi Keluarga Dalam Rangka Memperkuat Ketahanan Pangan di Tengah Pandemi Covid-19, Jurnal Ilmu Pertanian Tirtayasa, 1(2), 102-107.

Perwitasari, D. A., Amani, T., \& Tim KKN Desa Gending. (2019). Penerapan Sistem Akuaponik (Budidaya Ikan Dalam Ember) Untuk Pemenuhan Gizi Dalam Mencegah Stunting Di Desa Gending Kabupaten Probolinggo. Jurnal Abdi PancaMarga, 1(1), 20-24. 